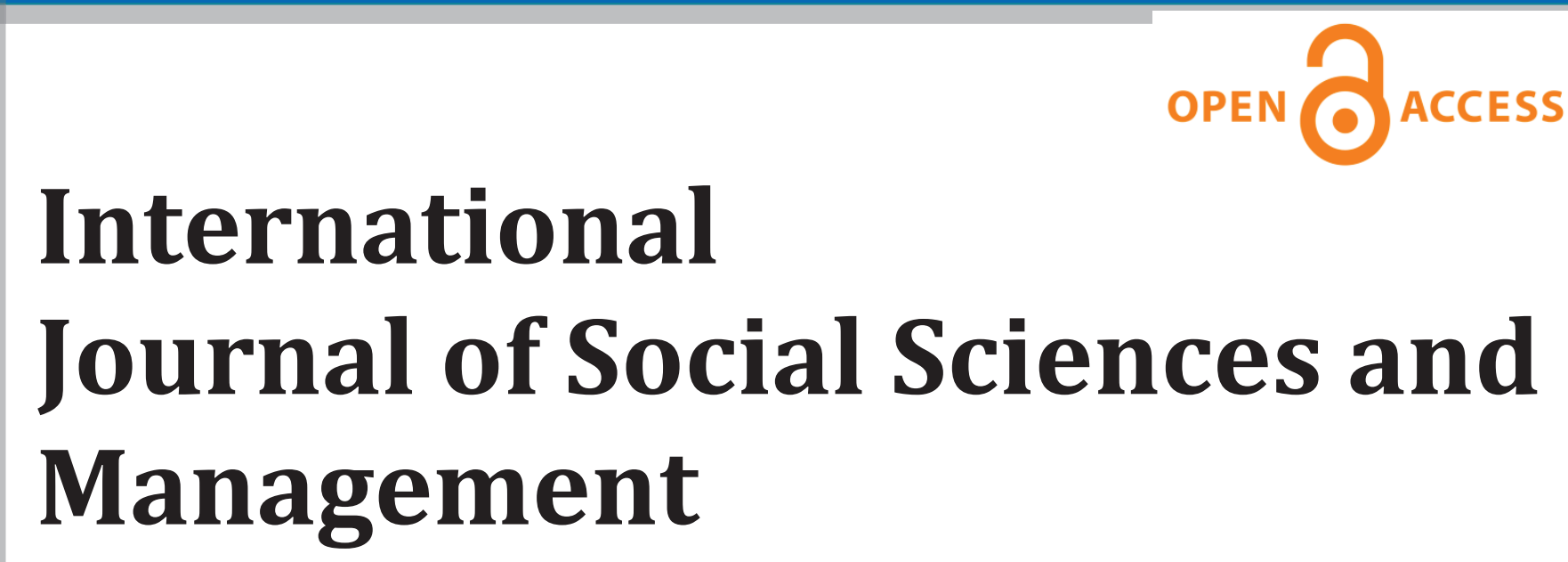

A Rapid Publishing Journal

ISSN 2091-2986

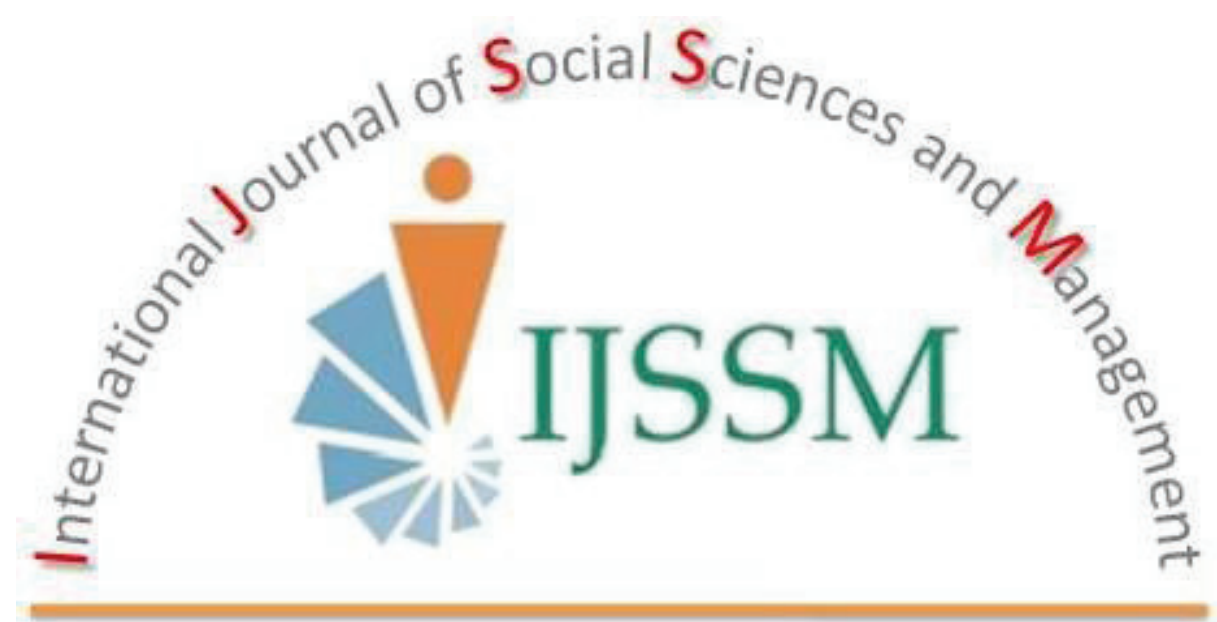

Available online at:

http://www.ijssm.org

\&

http://www.nepjol.info/index.php/IJSSM/index

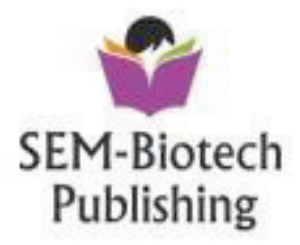




\title{
SUSTAINABLE DEVELOPMENT OF JARDHAR VILLAGE, UTTARAKHAND, INDIA THROUGH PARTICIPATORY LEARNING AND ACTION
}

\author{
R. K. Kamble \\ Department of Environmental Science, Sardar Patel Mahavidyalaya, Chandrapur 442 402, India \\ Email for Correspondence: rahulkk41279@yahoo.com
}

\begin{abstract}
Jardhar village is located in the Himalayan range of Chamba block of Tehri Garhwal district of Uttrakhand state of India. The village is divided into 9 wards and 17 hamlets at a stretch of $9 \mathrm{~km}$. The village comprises of about 285 families from general and scheduled caste (2001 census). The participatory learning action (PLA) methodology was adopted for the sustainable development of Jardhar village. A field study was carried out in summer 2013. During filed visit problem matrix analysis was carried out, which revealed 17 problems from the study area. In addition to this, reasons for causes of poverty were also assessed. The problems were ranked according to the priority of villagers from diverse socioeconomic background through PLA and suitable S\&T interventions were arrived through brainstorming activities. An integrated action plan was prepared which emphasize upon short term and long term measures to be adopted to overcome these problems and to move toward sustainable development of the Jardhar village. The interaction of all these measures for effective implementation has also been suggested.
\end{abstract}

Keywords: Sustainable development, Jardhargaon, Tehri Garhwal, Uttarakhand, Participatory Learning and Action

\section{Introduction}

Around $60 \%$ of the rural population in India lives in primitive conditions. Most of them have no access to electricity, necessary education and health services. Modern technologies have not reached these people even after 65 years of independence. Rural poverty causes large scale migration to cities which further lead to serious urban problems. Though a lot has changed with the changing times, still a lot depends on these lively villages which present the better half of India.

\section{Study Area}

Jardhar village (N 30019'53.3" E 78021'30.8", N 30²0'46.0" $\left.\mathrm{E} 78^{\circ} 20^{\prime} 8.0^{\prime \prime}\right)$ is situated in the picturesque valley of Chamba block of Tehri Ghadwal district of Uttarakhand state of India. It is situated at an altitude of about $1440 \mathrm{~m}$ above mean sea level. The village is situated approximately $20 \mathrm{~km}$ from the district headquarter Chamba. The geographical area of the village is 437.273 ha. The agriculturally cultivable land in the village is 185.495 ha. Irrigated area was 27.825 ha and non-irrigated area was 142.150 ha. As per 2001 census Jardhar village comprises of 15 hamlets with 282 families staying in 9 wards spread over $9 \mathrm{~km}$ stretch. Some wards were situated in close proximity while other was far away from each other. On one side of the village is the pine forest and village grassland. On the higher ridges was dense reserved forest comprising primarily of oak and rhododendron trees. The forests of Jardhargaon broadly fall under the Himalayan moist temperate forests category. The forests are species rich. Dominating species in the forest were oak, rhododendron, kaphal and chullu.

\section{Demography}

Out of the 282 families of the village, 206 belong to general category and 76 to Scheduled Caste. The population in 2001 was 1484 individuals in which 797 were females, 687 males from general category, whereas 149 females and 129 males from Scheduled Caste. The literacy rate was $55.25 \%$. Families below poverty line (BPL) were 100 according to the survey of 2002; out of which 65 families were from general category and 35 from Scheduled Caste. 


\section{Infrastructure}

The Jardhar village is connected with the Chamba block by a tar road. The wards of the village which are situated inside from the main road are connected by kachha road. The village was supplied with drinking water through stand posts at public places. Primary health centre (PHC) facility was not available in the village. The transportation facility was in poor state of condition. There was only a single bus (state bus) service in the morning and evening to cater the needs of villagers. Mobile phone connectivity was good and it was observed that at least one mobile phone was available in every household. Almost all houses had electricity connection except the houses of scheduled caste in ward 1. The availability of electricity was throughout the day and night and hardly any power cuts were reported.

The village had three government schools. A Panchyat Bhawan is located in ward 1. This is being used for conducting meetings and keeping records of various activities. The basic amenities like shops, haat and local market were absent in Jardhar village. For purchasing grocery and other small goods villagers have to go Chamba and for major shopping like for marriages they have to go to Rishikesh around $60 \mathrm{~km}$ away.

\section{Socio-economic Conditions}

The main source of income for majority of villagers was agriculture. Compared to general category, scheduled caste people were living in poor socio-economic condition; whose major occupation was blacksmith, masonry, carpentry and labourer. Most families had concrete house with good sanitary facilities while schedule caste people had kaccha houses with improper sanitary facilities. One of the major problem which was observed from the study area was migration of youngsters for education which left with only elderly people in the village. Some youngster had also gone abroad in search of jobs.

\section{Education and health}

The literacy rate of the village was $65.75 \%$. Male literacy rate was $86.34 \%$ and female was $48.75 \%$. Mostly men were educated up to 10th standard while women were literate just to read and write. Some young women who got married into the village were found to be graduate and XIIth standard pass. All the children of age group 6-14 were enrolled in school. The dropout rate was negligible in general category while dropout's rate was higher in scheduled caste families.

The village had three government schools and a private nursery. Two school were located in ward 1 whereas one school in ward 5. Out of the two schools in ward 1, one was primary school up to class 5 and another up to class 8 . The other school in ward 5 was providing education from class 1 to 5 . For further education from class 9 onwards students had to go to Nagdev Pathad village which was far away from the village and for further education they had to go to a only inter college which was located in Nagini village about $8 \mathrm{~km}$ from the village. Even though most people use mobile phones, computer literacy was negligible.

Health condition of villagers was found in good state, however in some individual lifestyle diseases such as diabetes, heart problem and blood pressure were observed. Medical facilities in terms of immunisation, pulse polio and family planning were properly carried out by Asha and ANM. On every Wednesday ANM visits different wards to solve medical problems of villagers. Maternity care was provided through a maternity centre which was located in ward 5. However, it was observed that family planning measures were not adopted properly in scheduled caste locality of ward 1. In some houses up to 5 children's were reported by villagers. Drinking water was tapped from natural springs from nearby mountains and was distributed to villagers through a steel pipeline under the project SWAJAL. The availability of water was sufficient throughout the year however; during summer season water scarcity was reported in some areas. To meet water demands of villagers' during such time water was provided through private tankers. In scheduled caste locality villagers had to go to nearby gadera (small nallha) to fetch the water up to four times a day to meet their daily water demands. A charge of Rs 10/- per month was charged towards water tax from villagers. No complaint was recorded from villagers towards quality of drinking water.

\section{Agriculture and land reforms}

The main occupation of villagers was agriculture. Cropping was carried out during Rabi and Kharif season. Rabi season (November to April) had crops like wheat, pea, potato, tomato, mustered, masur, chilly, chaulai, cabbage, cauliflower, potato; whereas in Kharif season (June to October) jhangora, mandua, potato, tomato and cabbage, rice, gehat, pulses, rajma, tomato, ladies finger, pumpkin, cabbage. The land use pattern of the village can be broadly classified into housing and agriculture land. The agriculture land can be further classified into irrigated and non irrigated one. The farms were situated on hilly terrain on both side of mountain up to plains at the confluence point of small nallha to Hemval River. A significant variation in cropping pattern was observed in hills and plain. In plains paddy, tomatoes, wheat and other crops were cultivated whereas, in hill jhangora and mandua. The crops produced were used to sell in nearby local market on individual basis. Paddy and wheat which was grown was used by the villagers to cater the needs to their household, they are not being sold in market.

Agriculture productivity was very low because of traditional indigenous agriculture practices. Mechanization of agriculture was very poor and most of the cultivable land was rain-fed. Fertilizer consumption was limited up to vegetable crops only, while other cereals are grown with 
organic farming practices in which farm yard manure was used. Hybrid seeds were being used in cultivation of vegetable crops only, which was too badly affected due to poor marketing practice. Contract farming practice were usually carried out by scheduled caste category people who were landless, which was indicative of the fact that these people are almost deprived of agriculture land. Agriculture extensions services in this area are poor. Damage done to crops by bears and monkeys was one of the major problem faced by the farmers.

\section{Animal Husbandry}

Animal husbandry was an integral part of the agriculture sector of the village. Villagers kept bullock for ploughing land; buffaloes for milk production; mules for transportation, goats for meat and dogs as companion and for security purpose. The average milk production of buffaloes was 8 litres. Bullocks and mules were found in healthy conditions and no disease was reported. Veterinary service was very poor in the village and nearest veterinary dispensary was in Chamba. The cost of bringing a veterinary doctor to the village for treatment was very high.

\section{Poverty, Unemployment and Livelihood}

Being a typical traditional Himalayan village, the prominent livelihood option for inhabitants was agriculture. However, marginal and scattered land holdings and rain-fed agriculture practices were some of the fundamental causes of poverty among the farmers. The primary features of poverty causing factors were scored using poverty matrix analysis (Table 2). After carrying out poverty matrix analysis six causes were identified for existence of poverty in the village.

Out of 100 BPL families, 65 were from general category and 35 from scheduled caste category. A high percentage of BPL families were indicative of the fact that most of the scheduled caste category families were marginal land holders or not having any land to practice farming. Poverty had created an imbalance of living standards among these inhabitants as evidenced by broken and damaged houses and poor health status.

In addition to agriculture, the villagers usually work in MNREGA and other community work as labourers for income generation. Cash crops cultivation was not practiced in upper region of the village primarily due to lacking of irrigation system. Only about $10 \%$ of total agriculture land was irrigated in area thus this leads to migration as an alternative to agriculture. Most of the agriculture land left as fallow land or otherwise taken on lease by landless scheduled caste families for contract farming. In such conditions they were entitled for only $50 \%$ share of total produce.

The BPL families primarily depend on public distribution system (PDS) for availability of food. Most of the families in the village had various fruit bearing plants such as plumes, khumani, chullu, akhrot, kaphal, aadu etc., scattered in their courtyard or in field.

\section{Participatory Learning and Action}

Preliminary survey of the village gave in-depth background information of it. Through participatory learning and action (PLA) approach and active participation of individuals from different backgrounds such as socio-economic, gender, caste, creed, occupation; problem preference ranking and causes of poverty was analysed. For problem preferences ranking a total of 17 problems were identified through the preliminary discussion with villagers. The villagers from different background were requested to rank these problems which they felt the most important and lest important. This preference ranking through PLA resulted in comprehensive problem identification at village level. The results are presented in Table 1 and 2. This ranking gave the priority of problems of the villagers which needs immediate attention.

\section{Action Plan for Sustainable Development}

After analysing problems which were pertinent in the study area through problem preference ranking following important problems were ranked. They are arranged according to their ranks from the community survey through participatory learning and action (PLA). They are as follows:

1. Destruction of agricultural crops by monkeys and pigs

2. Scarcity of drinking water

3. Crop diseases on chilli and chawalai

4. Non availability of hospitals and chemist

5. Weed problem such as khatta khad and b. Irrigation problem

6. Inadequate transportation facility

7. Unemployment

8. Late payments of wages in MNREGA

9. Non availability of banks

10. Collection of fuel wood

11. Lack of toilet and bathroom facility in scheduled caste locality

12. Absence of secondary and higher secondary schools

13. Selection of MNREGA work and road facility

14. No electricity connection

15. Improper distribution of BPL cards

16. Improper selection of pensioners

After ranking these problems an action plan was developed for sustainable development of the village which was integration of short term and long term measures. Table 3 depicts integrated action plan prepared for the sustainable development of the village. This action plan is an incorporation of technical, social, economic and scientific aspects to pave a way for inclusive sustainable development of the village. 
Table 1: Problem preference ranking

\begin{tabular}{|c|c|c|c|c|c|c|c|c|}
\hline $\begin{array}{l}\text { Persons } \rightarrow \\
\text { Problems } \downarrow\end{array}$ & Workers & House wife & Farmers & $\mathrm{SC}$ & Youth & Unemployed & Total & Rank \\
\hline Crop disease & 6 & 4 & 2 & 11 & 12 & 11 & 46 & 3 \\
\hline $\begin{array}{l}\text { Wild animals (Monkeys } \\
\text { and Pigs menace) }\end{array}$ & 5 & 1 & 3 & 12 & 7 & 10 & 38 & 1 \\
\hline Weed problem & 8 & 2 & 4 & 10 & 13 & 12 & 49 & 5 \\
\hline Fuel wood & 3 & 5 & 18 & 8 & 15 & 9 & 58 & 10 \\
\hline $\begin{array}{l}\text { Transportation facility } \\
\text { (Bus) }\end{array}$ & 10 & 15 & 5 & 9 & 6 & 5 & 50 & 6 \\
\hline Hospital and chemist & 11 & 6 & 10 & 7 & 8 & 6 & 48 & 4 \\
\hline Water scarcity & 4 & 3 & 6 & 5 & 14 & 8 & 40 & 2 \\
\hline Bank & 13 & 11 & 11 & 14 & 4 & 4 & 57 & 9 \\
\hline College & 16 & 16 & 14 & 13 & 2 & 1 & 62 & 12 \\
\hline Employment & 2 & 17 & 15 & 4 & 1 & 13 & 52 & 7 \\
\hline Toilets & 14 & 18 & 16 & 1 & 9 & 3 & 61 & 11 \\
\hline $\begin{array}{l}\text { Improper selection of } \\
\text { work in MGNREGA } \\
\text { scheme in wards }\end{array}$ & 12 & 10 & 7 & 17 & 16 & 2 & 64 & 13 \\
\hline Late payment of wages & 1 & 7 & 8 & 6 & 17 & 14 & 53 & 8 \\
\hline $\begin{array}{l}\text { Improper distribution of } \\
\text { BPL cards }\end{array}$ & 6 & 8 & 9 & 16 & 18 & 15 & 72 & 15 \\
\hline $\begin{array}{l}\text { Improper selection of old } \\
\text { age pensioners }\end{array}$ & 15 & 12 & 17 & 18 & 11 & 18 & 91 & 16 \\
\hline Lack of irrigation facility & 7 & 9 & 1 & 15 & 10 & 7 & 49 & 5 \\
\hline Electricity & 18 & 14 & 13 & 3 & 5 & 16 & 69 & 14 \\
\hline Road & 17 & 13 & 12 & 2 & 3 & 17 & 64 & 13 \\
\hline
\end{tabular}

Table 2: Causes of Poverty

\begin{tabular}{lllllllll}
\hline $\begin{array}{l}\text { Persons } \rightarrow \\
\text { Problems } \boldsymbol{\Downarrow}\end{array}$ & Workers & House wife & Farmers & SC & Youth & Unemployed & Total & Rank \\
\hline $\begin{array}{l}\text { Marginal land } \\
\text { holdings/Landless }\end{array}$ & 1 & 1 & 1 & 1 & 3 & 4 & 11 & $\mathbf{1}$ \\
Education & 6 & 4 & 4 & 4 & 5 & 2 & 25 & $\mathbf{5}$ \\
Low wages & 3 & 3 & 5 & 5 & 2 & 3 & 21 & $\mathbf{3}$ \\
Indebtedness & 4 & 6 & 2 & 2 & 4 & 6 & 24 & 4 \\
Liquor & 5 & 5 & 6 & 6 & 6 & 5 & 33 & $\mathbf{6}$ \\
Employment & 2 & 2 & 3 & 3 & 1 & 1 & 12 & $\mathbf{2}$ \\
\hline
\end{tabular}


Table 3. Integrated action plan for sustainable development

\begin{tabular}{|c|c|c|c|c|}
\hline \multirow[t]{2}{*}{ Rank } & \multirow[t]{2}{*}{ Problems } & \multicolumn{3}{|c|}{ Action Plan } \\
\hline & & rt term measures & Lon & rm measures \\
\hline I & $\begin{array}{l}\text { Destruction of } \\
\text { agricultural crops } \\
\text { by monkeys and } \\
\text { pigs }\end{array}$ & $\begin{array}{ll}\text { - } & \text { Fencing for the farms } \\
\text { - } & \text { Electric fencing of the farms on solar radiation } \\
\text { - } & \text { Bursting of crackers } \\
\text { - } & \text { Use of chilli powder } \\
\text { - } & \text { Use of soft drink cans }\end{array}$ & $\bullet$ & $\begin{array}{l}\text { Crop insurance } \\
\text { schemes should } \\
\text { be introduced }\end{array}$ \\
\hline II & $\begin{array}{l}\text { Scarcity of } \\
\text { drinking water }\end{array}$ & 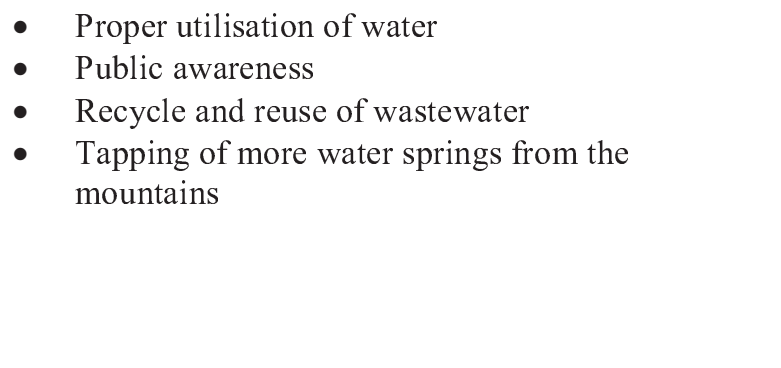 & $\bullet$ & $\begin{array}{l}\text { Rejuvenation } \\
\text { of Chahal in } \\
\text { Chak area of } \\
\text { villages } \\
\text { situated in } \\
\text { mountains } \\
\text { Construction of } \\
\text { check dams }\end{array}$ \\
\hline III & $\begin{array}{l}\text { Crop diseases on } \\
\text { Chilli and } \\
\text { Chawalai }\end{array}$ & $\begin{array}{l}\text { - Use of bio-pesticides } \\
\text { - Application of wooden ash }\end{array}$ & • & $\begin{array}{l}\text { Integrated pest } \\
\text { management }\end{array}$ \\
\hline IV & $\begin{array}{l}\text { Non availability of } \\
\text { Hospitals and } \\
\text { chemist }\end{array}$ & $\begin{array}{l}\text { B.Sc. graduate individuals from the villages } \\
\text { should be given training for the first aid and } \\
\text { nursing } \\
\text { - Frequency of visits of Asha and ANM should be } \\
\text { increased } \\
\text { - A well equipped chemist shop should be opened } \\
\text { - Frequency of mobile medical facilities should be } \\
\text { increased }\end{array}$ & 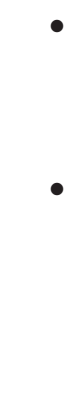 & $\begin{array}{l}\text { A primary } \\
\text { health centre } \\
\text { should be } \\
\text { developed } \\
\text { Veterinary } \\
\text { facilities } \\
\text { should be } \\
\text { provided on } \\
\text { frequent basis }\end{array}$ \\
\hline V & $\begin{array}{l}\text { Weed problem } \\
\text { such as khatta } \\
\text { khad and irrigation } \\
\text { problem }\end{array}$ & $\begin{array}{l}\text { - In depth ploughing and selective removal of the } \\
\text { bulbs of khatta khad should be carried out } \\
\text { - During summer season the weed should be } \\
\text { removed completely from the farm and can be } \\
\text { burnt } \\
\text { - Farm tanks should be constructed } \\
\text { - Interlinking of tanks can be carried out along with } \\
\text { interlinking of farms }\end{array}$ & & $\begin{array}{l}\text { More R\&D } \\
\text { should be } \\
\text { carried out for } \\
\text { effective } \\
\text { removal of the } \\
\text { same from the } \\
\text { field } \\
\text { Construction of } \\
\text { check dams } \\
\text { should be } \\
\text { carried out } \\
\text { Rejuvenation } \\
\text { of Chahal in } \\
\text { the Chak area } \\
\text { of villages } \\
\text { situated in } \\
\text { mountains for } \\
\text { proper } \\
\text { recharging of } \\
\text { streams and } \\
\text { water table }\end{array}$ \\
\hline
\end{tabular}


Table 3. Integrated action plan for sustainable development (Contd.)

\begin{tabular}{|c|c|c|c|c|}
\hline \multicolumn{3}{|c|}{ Problems } & \multicolumn{2}{|c|}{ Action Plan } \\
\hline & & rt term measures & Long & rm measures \\
\hline VI & $\begin{array}{l}\text { Inadequate } \\
\text { transportation } \\
\text { facility }\end{array}$ & $\begin{array}{l}\text { - Transport facility should be increased from twice } \\
\text { a day to four times a day }\end{array}$ & $\bullet$ & $\begin{array}{l}\text { Government } \\
\text { should } \\
\text { initiative on } \\
\text { reduction of } \\
\text { transport taxes } \\
\text { and } \\
\text { subsidy/loan on } \\
\text { taxi/private } \\
\text { buses }\end{array}$ \\
\hline VII & Unemployment & $\begin{array}{l}\text { Small and medium scale industrial activities } \\
\text { should be encouraged viz. fruit and vegetable } \\
\text { based industries, essence stick and candle making, } \\
\text { aquaculture, mushroom cultivation, snacks } \\
\text { making from indigenous cereals, beekeeping, }\end{array}$ & • & $\begin{array}{l}\text { Establishment } \\
\text { of ITI and } \\
\text { other technical } \\
\text { institutes }\end{array}$ \\
\hline VIII & $\begin{array}{l}\text { Late payments of } \\
\text { wages in } \\
\text { MNREGA }\end{array}$ & $\begin{array}{l}\text { - Government should ensure timely payment to be } \\
\text { given under such schemes }\end{array}$ & & \\
\hline IX & $\begin{array}{l}\text { No availability of } \\
\text { banks }\end{array}$ & $\begin{array}{l}\text { Extension counters of nationalised or Rural banks } \\
\text { should be encouraged }\end{array}$ & & \\
\hline $\mathrm{X}$ & $\begin{array}{l}\text { Collection of fuel } \\
\text { wood }\end{array}$ & $\begin{array}{l}\text { - Introduction of wood gas stoves should be } \\
\text { promoted } \\
\text { - Smokeless stoves, solar cooker, solar water heater } \\
\text { should be encouraged by the Govt. }\end{array}$ & $\bullet$ & $\begin{array}{l}\text { Community } \\
\text { based solar } \\
\text { cooker and } \\
\text { water heater } \\
\text { schemes should } \\
\text { be introduced }\end{array}$ \\
\hline XI & $\begin{array}{l}\text { No toilet and } \\
\text { bathroom facility } \\
\text { in scheduled caste } \\
\text { locality }\end{array}$ & $\begin{array}{l}\text { - Low cost sanitation should be introduced (pit } \\
\text { hole) } \\
\text { - Wastewater collection should be carried out }\end{array}$ & $\bullet$ & $\begin{array}{l}\text { Treatment of } \\
\text { wastewater by } \\
\text { Halofilters }\end{array}$ \\
\hline
\end{tabular}

\section{Conclusion}

From PLA activity existing problems which were faced by villagers and causes of exiting poverty were identified. These problems were ranked according to preferences of villages for to know priority which needs immediate attention. An integrated action plan was suggested to overcome these problems. The action plan comprises of short term and long term measures. The action plan was prepared taking into consideration scientific, technical, social, economic, innovative measures to pave the way for sustainable development. These types of activities can be replicated through various parts of the world as they involve people from whom development is carried out.

\section{References}

Kalpavriksh. (2008). Jardhargaon Community Conserved Area, Uttarakhand, India.

Malhotra, P. (2004). Agriculture and Food Security-A Peoples Movement for Conservation and Livelihoods in Jardhargaon, Uttaranchal. In Seeds of Hope Lokayan. Planning Commission. 